\title{
Editing English Coursebook Manuscripts : What Skills should be prepared?
}

\author{
Djatmika $^{1}$, Riyadi Santosa ${ }^{2}$, Sri Marmanto ${ }^{3}$, Tri Wiratno ${ }^{4}$, Agus Hari Wibowo ${ }^{5}$ \\ djatmika@staff.uns.ac.id ${ }^{1}$, riyadisantosa@staff.uns.ac.id ${ }^{2}$, marmanto@staff.ns.ac.id ${ }^{3}$, \\ wiratno.tri@gmail.com ${ }^{4}$, agushari67@staff.uns.ac.id ${ }^{5}$ \\ English Department, Faculty of Cultural Sciences, Universitas Sebelas Maret \\ J1. Ir. Sutami 36 A, Surakarta, Indonesia 57126 1,2,3,4
}

\begin{abstract}
This paper talks about the skills needed by editors in assessing and improving English coursebook manuscripts at PT. Intan Pariwara. Fifteen drafts representing chapters of one English book manuscript became the objects of study. Data in the forms of linguistic features were collected from the drafts. In addition, non verbal aspects in the forms of pictures were also collected as suporting data. The collected data were analysed to see whether the editor of the draft has done her/his jobs well. The results show that several weaknesses were found in the edited drafts related to text structure, grammar quality, words choice, and exploitation of pictures for the book. The findings are expected to be input for the publisher to upgrade their editors for skills related to these aspects.
\end{abstract}

Keywords: editor, skills, draft, linguistic features

\section{Introduction}

A research conducted by Djatmika, et al. showed that some textbooks both originally written by Indonesian author and translated from English by Indonesia translators have poor language exploitation and translation quality. ${ }^{1}$ Weaknesses are found in such texts in the way the book contents are presented and in the way the source texts are presented in translation version. The skills of the authors and translator in formating texts, in constructing grammatical structures, in selecting words as well as in exploiting other semiotic modes for the publication are believed to have influence to the quality of the drafts before they are ready for editing process. On that account, the role of editors for such drafts is very important. The language skills mastered by the editors will strongly support their work in improving the draft to be ready for publication. Various weaknesses in grammar and vocabulary selection will be easily identified by the editors, and at the same time they will be able to make corrections for improvement for the manuscripts.

There are two types of editing staffs working at Indonesian publishers,i.e. editors for translation drafts, and editors for textbook drafts written by Indonesian authors including draft of English coursebook which becomes the object of the research. To conduct their jobs, editors for drafts of English coursebook must have good quality of English as they improve drafts for teaching materials for the next publishing process. Meanwhile, editors for translation drafts have more challenging taks - they must have good linguistic knowledge in both source language and target language. In addition, the editors must also have translating skill to be able to improve the 
translation drafts they are responsible with. This relates to the fact that the editors must be able to find weaknesses in the draft that they are editing, especially problems with text structure and text textures in terms of grammar quality and word selection performed by the original translator.

However, many editors of textbook and translation texts show unsatisfied skills of language as well as translation. They can not performed their jobs maximally as they often miss verbal weaknesses existing in the drafts as well as non verbal ineffectiveness exploited in the drafts such as pictures as visual mode. This fact is proofed by the quality of books have been published and distributed in the society. ${ }^{1}$ Related to such a fact, the editors need to improve their language and translation skills, especially skills in selecting and formatting discourse unit to become texts in certain genres, skills in exploiting grammatical rules for sentence constructions, skills in selecting words, and also skills in providing non verbal aspects for the textbook drafts. $3,4,5,6$

To limit the scope of discussion, this paper presents the English language skills performed by the editors of drafts of English coursebook related to text structure and text texture. The first aspect represents the editors' skills in identifying and correcting deficiencies related to the type of text and discourse unit used for certain types of texts in the drafts; while the second aspect shows their skills in finding and correcting deficiencies related to grammatical quality and vocabulary selection. In addition, the discussion also involves the editors's sensitivity in identifying weaknesses in selenting and presenting pictures for the coursbook drafts.

\section{Methods}

Fifteen chapters of draft for English coursebook were selected to analyze. Data in the forms of linguistic features and other semiotic modes were collected from each chapter. The former involved discourse units for the teks structure, grammar quality and word choice for the draft. Meanwhile, the latter is represented by pictures or photographs exploited to support the presentation of teaching materials in the book draft. The collected data were analysed to see whether the editor of the edited draft had undertaken his job properly so that the draft was ready for publication or for quality assessment.

\section{Finding and Discussion}

As a research partner, PT. Intan Pariwara, Klaten provided 15 modules which were prepared for the publication of an English textbook for grade X SMA / MA. The analysis for each module of this book was focused on several aspects, namely aspects of the structure and texture of the texts for the teaching materials and other aspects or modes that support the presentation of these English teaching materials. The findings from each of these aspects are presented as follows.

\subsection{Quality of Texts' Structure}

Six types of text are introduced for the students in the module drafts, namely e-mail / letters, announcements, descriptive, recount, and narrative. Texts of emails and letters are presented as a means of introduction. Students are given several email models and introductory 
letters with several obligatory as well as optional discourse units. One model of introductory email is contructed with a unit that is actually not appropriate for such a text-such a unit says:

For your information, I have an elder brother, Denis. He studies at Brawijaya University. He returns home once a month. So, I seldom meet him personally, but we always chat using social media very often. My father, Mr. Janson is a teacher and my mother, Mrs.Rahayu, is a police woman.

Descriptive texts are presented in two modules / two units. The materials contained in the texts are tourism spots. Students are trained with the skills to describe tourist attractions in various regions in Indonesia. Meanwhile, recount texts are provided in three units with variations of recount biographies for living and dead figures (heroes). Recount biographical texts for living figures show grammatical inconsistency as the texts accommodate simple past tense, present perfect tense and simple present tense in telling the life of the figures - whereas the linguistic features for a recount suggest only simple past tense in presenting the chronological events.

In addition, there are texts with unclear genre types, such as in Chapter 7 Great Achievement. The reading passage presented in such a chapter in one part behaves like a description, and in other it shows a recount linguistic features. In rather similar case, the reading text in Chapter 8 is claimed to be a recount, but one part of such a text represent a complicationan obligatory unit of a narrative text.

Narrative texts are presented in 3 units with variations in contents, namely fairytale, legend, and folktale. All of these variations are explained as a narrative text consisting of orientation, complication, resolution, and reorientation / coda. This concept is not correct. It should be explained that there are three obligatory units, namely orientation, complication, and resolution - and there are two optional units, namely evaluation and coda. A wrong concept on narrative text structure is represented by the introduction of reorientation in the end of such a text. This unit is actually a part of a recount, so suggesting it as the ending part of a narrative seems to be misleading. Furthermore, the author of the coursebook does not present evaluation as one of optional units of a narrative. This does not enrich students with knowledge of units supporting the text structure of stories. As each of the three chapters that accommodate a text of this type presents a different text, namely a fairytale, a legend, and a folklore for eah, then what linguistic features differentiate each of the three texts should be explained to the students.

\subsection{Quality of Texts' Texture}

\subsubsection{Grammatical Mistakes}

The draft is prepared for English textbook for year one of senior high school in Indonesia. Therefore, the materials presented should be free from mistakes in English language exploitation, especially those related to the structure of the text as discussed in the section above and also related to grammatical and lexical quality. Related to English grammar quality, the draft show wrong concept of grammar rules presented for learning materials and several grammatical mistakes existing in learning instructions, readingn texts, and in other parts of the draft.

In general, the types of grammatical errors that still appear in this draft textbook are as follows. Problem in parallel structure appears on each front page of a chapter that represents the learning map. Some of the competencies that are expected to be achieved by students after following the learning process by using the module should be in parallel structur - and gerund 
could be exploited for the parallel forms. For example, a chapter entitled Let's Talk about Self offers Asking for language skills and giving information about oneself and family relationships, E-mail and letters, and language features (grammar) as learning materials. They are presented inconsistently in the learning map. Using the form of gerunds for each subtitle of the material will make the presentation better, namely becoming Asking for and giving information about oneself and family relationships, Making E-mails and letters, and Understanding language features (grammar). A parallel form like this will be more grammatically effective and consequently will provide a clear message for the readers. This strategy should also be applied to the sub-material under each of the three sub-headings, which are presented in the table below.

Table 1 Revised Learning Map

\begin{tabular}{|c|c|}
\hline Original Expressions & Revised Expressions \\
\hline $\begin{array}{l}\text { Listen to the dialogs and understand the } \\
\text { contents. }\end{array}$ & $\begin{array}{l}\text { Listening to the dialogs and understanding the } \\
\text { contents. }\end{array}$ \\
\hline Identify the expressions and language features & Identifying the expressions and language \\
\hline $\begin{array}{l}\text { of dialogs to ask for and give information about } \\
\text { oneself. }\end{array}$ & $\begin{array}{l}\text { features of dialogs to ask for and give } \\
\text { information about oneself. }\end{array}$ \\
\hline $\begin{array}{l}\text { Make conclusion on how to ask for and give } \\
\text { information about oneself. }\end{array}$ & $\begin{array}{l}\text { Making conclusion on how to ask for and give } \\
\text { information about oneself. }\end{array}$ \\
\hline $\begin{array}{l}\text { Introduce oneself, spoken and written, } \\
\text { accordingly. }\end{array}$ & $\begin{array}{l}\text { Introducing oneself, spoken and written, } \\
\text { accordingly. }\end{array}$ \\
\hline $\begin{array}{l}\text { Read and understand the contents of e-mails and } \\
\text { letters. }\end{array}$ & $\begin{array}{l}\text { Reading and understanding the contents of } e \text { - } \\
\text { mails and letters. }\end{array}$ \\
\hline $\begin{array}{l}\text { Identify the contents and structures of e-mails } \\
\text { and letters. }\end{array}$ & $\begin{array}{l}\text { Identifying the contents and structures of } e \text { - } \\
\text { mails and letters. }\end{array}$ \\
\hline Write e-mails dan letters. & -mails dan letters. \\
\hline Identify $p$ & onouns \\
\hline $\begin{array}{l}\text { Draw conclusion about pronouns and how to } \\
\text { use them. }\end{array}$ & $\begin{array}{l}\text { Drawing conclusion about pronouns and how } \\
\text { to use them. }\end{array}$ \\
\hline $\begin{array}{l}\text { Use pronouns in dialogs, e-mails and letters } \\
\text { correctly. }\end{array}$ & $\begin{array}{l}\text { Using pronouns in dialogs, e-mails and letters } \\
\text { correctly. }\end{array}$ \\
\hline
\end{tabular}

Gerund presented in the right column of the table above makes this chapter's learning map presented in a parallel structure. The quality of this grammar makes the learning map presentation more effective with messages that are easier to digest for prospective book users. The improvement model for the learning map on the first page of this chapter can be applied to other chapters of the English textbook draft. Grammatical mistakes related to the form of gerunds are also found in the text reading material as exemplified by the following two sentences:

1. I love correspondence.

2. I hope I'll get a lot of benefits by corresponding with her.

The two sentences serve as examples in the reading text, so the minor mistakes of the two sentences above should be corrected to

3. I love correspondencing.

4. I hope I'll get a lot of benefits by correspondencing with her. 
In addition to the mistakes related to gerund, there are other minor mistakes found in the draft such as mistakes related to the exploitation of coordinating conjunction. These conjunctions--and, but, or, so are grammatically exploited to combine two or more simple clauses with the position always between the clauses they combine. Moreover, English grammatical rules also show that conjunctions are only used in the construction of compound sentences or complex sentences. In connection with this rule, the draft still shows a few simple sentences that are initiated by a conjunction as presented in the examples below.

5....Sifa is interestedin becoming her friend. So, she decided to send an e-mail to Cleopatra

6. I dream to make dramas in English. So, would you teach me how to learn and master English with British accent?

7. But none of them have been published.

The three examples above show the use of the so and but which starts a simple sentence. This is anAn example of grammar that is not effective to be used as modeling for prospective users of this textbook. Replacing the conjunction so with therefore, and but with however will be one of the strategies that editors can do to correct this type of grammatical mistake, for example .

8. ...Sifa is interested in becoming her friend. Therefore, she decided to send an e-mail to Cleopatra

9. I dream to make dramas in English. Therefore, would you teach me how to learn and master English with British accent?

10. However, none of them have been published.

Other types of mistakes related to conjunctions are unneeded conjunctions in sentence construction. The English grammatical rules show that conjunctions are used in the construction of complex sentences. Combining two clauses will require a conjunction, whereas combining three clauses will require two conjunctions, and so on. In connection with this grammatical principle, there is a sentence construction that should have a simple sentence structure, but the author of the book inserts a conjunction in it. Insertion of conjunctions into structures that do not actually require this makes the construction ineffective. The construction of the sentence can be seen below.

\section{What situation which make the senders write the cards?}

This simple question sentence is used by the writer to stimulate the readers comprehend the reading text. The use of conjunctions which - which seems to occur due to the influence of the Indonesian language rules - makes the question sentence less grammatical, thereby removing the conjunction from its position in the structure will actually make the sentence more effective.

\section{What situation makes the senders write the cards?}

Moreover, related to the case of Indonesian language interference toward English sentence constructions used in the draft, the author also showe an interference in term of language style represented in several sentences in reading texts. Put in other words, several 
sentences have Indonesian deep structure but they are stated in English. Hence the English sentences sound and have Indonesian style. The following two sentences show the case.

13. But it tends they break the traffic rules.

14. Those are for your own good.

The two sentences above have a grammatical weakness in addition to being expressed in a non-English style. The first sentence begins with a conjunction which is not grammatically effective. In addition, the expression of it tends in the sentence makes this construction sound Indonesian even though it is stated in English. The author seems to say "Tapi cenderungnya mereka melanggar aturan lalu lintas" in English language; therefore, the English version shows ineffective grammatical construction. A more English expression can be suggested as "However, they tend to break the traffic rules".

Meanwhile, the second sentence shows a mistake in the choice of the word good which should be goodness. Even though it has been grammatically improved, this expression still sounds Indonesian. Modifying the word order to become "They are good for you" can be one solution of improvement- the message will be delivered effectively in an English style of expression. In addition, the other two types of grammatical mistakes represent subject-verb agreement and the use of tense. The former shows a mistake of using a non-referent pronoun as the subject of a construction which is paired with a wrong verb form in a sentence of But none of them have been published. The word none of them is always considered singular, so it needs a singular verb. The sentence should be modified to be "However, none of them has been published.". Like the mistake related to conjunction above, the word but in this sentence also shows an ineffective usage of conjunction which initiates a simple sentence. On that account, replacing such a conjunction with however can make the construction better. Finally, the last grammatical error is the selection of simple present tense to tell something happening in the past as shown in the following sentence.

\section{I request her to become my penpal.}

As the sentence above is used in a recount text to express something happening in the past, then the tense form does not really support the linguistic features needed by such a text. It must be replaced by simple past tense .

The draft of English textbook also has wrong concepts of grammar that are presented as teaching materials in a part named as Grammar Note. This section explains certain English grammar rules which are exploited as teaching materials in each chapter of the book. On that account, if the grammar concept provided by the section is wrong, then this will be misleading. The first wrong concept of grammar is accommodated by Grammar Note section of Chapter I of the draft explaining and introducing English pronouns. The author presents the pronouns in a table for subjective, objective, and possessive pronoun as shown below. 


\begin{tabular}{ccccccc}
\hline & & Singular & & & \multicolumn{2}{c}{ Plural } \\
& Subjective & Objective & Possessive & Subjective & Objective & Possessive \\
\hline $1^{\text {st }}$ person & I & me & mine & we & us & ours \\
$2^{\text {nd }}$ person & you & you & your & you & you & your \\
$3^{\text {rd }}$ person & he & him & his & they & them & theirs \\
& she & her & hers & & & \\
& it & it & its & & &
\end{tabular}

As the focus of this grammar presentation is on pronouns, the writer does not include the changes in possessive adjective such as my, your, his, her, our, their, and its. Including these words in the presentation must actually be very beneficial for the students because possessive adjectives are really parts of the conjugating forms of English pronouns. Furthermore, exercises in the chapter also include possessive adjectives as the materials. In addition, another misconception also occurs for pronoun its which is presented in the table as a possessive pronoun which should be possessive adjective-English does not have its as possesive pronoun. Revision for the table and presentation is recommended for the grammar section improvement as shown by the modified table below.

Table 2 Modified Table for Pronouns

\begin{tabular}{ccccccccc}
\hline & Subject & Object & $\begin{array}{c}\text { Singular } \\
\text { Poss. } \\
\text { Adj. }\end{array}$ & Poss. & Subject & Object & $\begin{array}{c}\text { Poss. } \\
\text { Adj. }\end{array}$ & Poss. \\
\hline $1^{\text {st }}$ person & I & me & My & mine & we & us & Our & ours \\
$2^{\text {nd }}$ person & you & you & Your & your & you & you & Your & your \\
$3^{\text {rd }}$ person & he & him & His & his & they & them & their & theirs \\
& she & her & Her & hers & & & & \\
& it & it & its & & & & &
\end{tabular}

The second wrong grammar concept is presented in Grammar Note of Chapter 4. The material is related to noun phrase which has a noun head and several modifiers. Instead of introducing various classes of word that can modify the head noun, the author only focuses on types of adjective that can be modifiers for the noun head in a noun phrase. However, in the column of adjective representing material for modifier, the author also includes nouns as examples for this type of adjective. This wrong example is presented in the following table designed by the author.

\begin{tabular}{lcccccccc}
\hline Det & & \multicolumn{9}{c}{ Adjectives } \\
& opinion & size & shape & age & color & origin & material & \\
\hline a & nice & small & -- & new & blue & balinese & wooden & statue \\
the & pretty & little & slim & young & -- & african & -- & girl \\
the & best & -- & -- & -- & white & -- & sandy & beach \\
-- & yummy & small & circular & -- & -- & -- & fruit & pudding
\end{tabular}

Because the Modifier that is introduced is only Adjective and its types, the word fruit in the material column is a misconception. Fruit is a noun and indeed a noun can be a Modifier for Noun Head in a Noun Phrase, but this is a modifying noun, not an adjective. This wrong 
example is also exploited in the exercises following the material presentation. Students are to identify types of adjectives that modify a noun head in a noun phrase. However, the author provides three noun phrases in which one of the modifers is a noun such as beautiful large bamboo house, bubbling mud pit, and steep winding stone road with bamboo, mud, and stone as modifying nouns for a noun head of a noun phrase.

\subsubsection{Wrong Choice of Words}

The draft only show a few of vocabulary problems, namely problems related to spelling, word selection, and names of language function. The first problem happens with the name of grammar section of each chapter, GAMMAR NOTE. The loss of a letter of $\mathrm{R}$ in the subtitle, even though a minor error, can significantly reduce the quality of the draft book, this subtittle appears in every chapter of the draft book.

The other word problem is related to proper names of school which are exploited in reading texts as teaching materials. The name of the school that is used imaginatively both in conversation and in reading text, should not represent a real referent in the real life, such as SMAN 2 BANDUNG. The proper name of SMAN 2 BANDUNG can be elaborated as follow. SMAN is an acronym for Sekolah "school" Menengah "high" Atas "senior" Negeri "state". Meanwhile, number 2 means that the school is the second school established in the city of Bandung. This school really exists in Bandung city. It is better for the author to use imaginary names of school in the conversation or reading texts as teaching material in the draft. If s/he wants to use state school, then s/he must be sure that the state school can not be found in one city. For example, if Solo city only has 8 state senior high schools, then the author can have SMAN 9 Solo as a proper name of school as part of teaching materials. The other suggested school name selection is using imaginary private school. However, the chosen names must sound academic such as SMA HARAPAN BANGSA, or SMA TUNAS BANGSA, and not SMA HARAPAN JAYA which seems to rather represent name of a business insitution, like a motor dealer, than a school.

Meanwhile, a few semantically wrong chosen words are found in the draft. One instruction for exercises says "Attach your email and reply on the classroom wall magazine". The exploitation of the word attach in that instruction is ineffective to send the message. Replacing it with the word post improves the effectiveness of the instruction to be "Post your e-mail and reply on the classroom magazine". The same error occurrs for the title of Chapter III, "Stating Intention". Pragmatically the word intention represents the pragmatic force of an utterance. Looking at the contents of the material presented in this chapter, then such a word should be replaced by the word plan. "Stating a plan" is more representative for the chapter.

Related to language function, two inappropriate uses of utterances exist in the draft. In Dialog 3 page 8, an utterance of "Hi Keiza, What are you buying?" is used to represent a greeting in English. The choice of utterane like this is not in accordance with the pragmatic behavior of English native speakers. They greet using "Good morning, How are you?, and so on, whereas "What are you buying?" is a Javanese way of greeting. Put in other words, an interrogative utterance executed for a ritual talk or for an icebreaker is Javanese pragmatic way, not English one. For an English native speaker, a question forwarded to greet her/him might be understood as a personal question for her/him, not a greeting - and this sounds rude for her/him.

The other pragmatic problem is related to the context elaboration backgrounding a dialog in Activity 9, Chapter I. The context configuration says: Nadim and Tigor are at the canteen. They meet Firda, Nadim's friend at Junior High School. Nadim is introducing her to 
Tigor. This configuration presents the dialog in which Nadim introduces Firda (his junior high school friend) to Tigor. Next, Nadim offers her a treatment for lunch. The contents of the conversation become weird because the context elaboration says Nadim and Tigor are at the canteen - the expression of at the canteen does not always represent that they are having lunch. It could be that the Nadim and Tigor were just sitting in front of the canteen, or just standing and chatting in one part of the canteen building, and so on. Thus, if the imagination is awakened they both just sit in the canteen and are not eating, then a generous speech offering Firda to order a meal and Nadim who will pay it will be strange. For this reason, the context cinfiguration should be improved by by saying that Nadim and Tigor are having lunch at the school canteen. This context configuration gets the dialog make sense.

\subsubsection{Weakness in other Mode}

In addition to verbal exploitation, the English textbook draft also shows weaknesses related to other modes, especially visual modes. There are three types of weaknesses that have not been touched by the editor, namely the cover image as the front view of the draft of this book presents a picture of some students in junior high school uniforms. Meanwhile, the draft of this book is entitled: ENGLISH LITERACY: English for SMA / MA Grade X. The combination of the title presentation with this picture does not seem appropriate. As this visual weakness appears on the cover page, it could be that this error will immediately attract the attention of the propective users as the representation of the draft quality.

Furhermore, the photographs which are used as visual aspects of the material presentation still need to be improved in quality. For example, the technique of taking pictures for the context of the painting exhibition in Chapter II page 20 is still not optimal. The available images do not represent a natural painting exhibition. The picture still looks like a big house with lots of paintings. This case occurs for several shooting contexts. On the other hand, other types of images, especially those related to tourist attractions or historic buildings, mostly already look natural. However, the author should consider the copyright issue when downloading pictures from internet.

\section{Discussion}

Analysis of the linguistic aspects of the book draft having passed the editing process shows that many things have been handled by the editor well. English language exploitation was done effectively for most parts of the draft such in presenting the learning materials as well as the language exercises. Only a few of weaknesses are found in the manuscript under four domains such as text structures and discourse units, grammar quality, words choice, pragmatic behavior, and visual mode supporting the verbal aspect of the draft. These weaknesses could indicate that the editor of the draft missed them which might be due to her/his English influency including text illiteracy.

For the first weakness, the editor need to increase her/his understanding of text types and discourse units needed for each of text. Moreover, s/he must also know the social function of each type, so that discourse units - either the obligatory or the optional ones-for such a type are selected and arranged properly. The text structure must be supported by proper linguistic features; on that account the editor must understand well what featurea are needed by each type of text. Such features are realized in grammar quality and words choice. In addition the linguitic features, the editor must also know English pragmatic behavior-s/he is demanded to judge whether utterances exploited by the book writer in the book draft are already approriate with the 
English way in pragmatic behavior or not. Finally, the editor is also required to be able to assess whether pictures or photos displayed in the book draft are applicable or not-not only in accordance to the content of the learning materials, but also in relation to the copy right of those which are downloaded from internet. Icreasing the skills in exploiting these aspect might help an editor do her/his jobs in consequency the improved skills will improve the quality of the edited drafts. $^{7}$

\section{Conclusion}

Editors have big jobs in preparing book drafts for the next publishing process. Assessing, correcting and improving the drafts should be performed well to make them better and ready for publication. The editor of the English book draft being analysed in this reseach shows weaknesses in several aspects, namely in exploiting text structure and texture representing the verbal aspect of the draft as well as in visual aspect in the forms of photos and pictures. Skill improvement for these aspects are recommended for the editor so that s/he will have better performance in doing her/ his job.

\section{References}

[1] Djatmika, Wibowo, A.H., \& Dewi, I.K. (2014). The Quality of English Translation Version of Bilingual Books of Physics and Social Science. Humaniora. Vol. 26. No. 3.

[2] Sharpe, L.T. \& Gunther, I. 1997. Editing Fact and Fiction A Concise Guide to Book Editing. Cambridge: Cambridge University Press.

[3] Eggins, S. (1994). An Introduction to Systemic Functional Linguistics. London: Pinter Publishers

[4] Gerrot, L. \& Wignell, P. (1995). Making Sense of Functional Grammar. Cammeray: AEE.

[5] Halliday, M.A.K. (2004). An Introduction to Functional Grammar. London: Edward Arnold

[6] Djatmika, Khrisna, D.A., \& Nuraeni, A. 2012. Systemic strategis to improve the readability of the English version of Indonesian children stories. KATA. Vol 14 No 2.

[7] Djatmika, Primasita, A.P., \& Priyanto, A.D. (2011) Strategi Meningkatkan Kualitas Olah Bahasa Untuk Cerita Pendek Tulisan Siswa Sekolah Dasar Dengan Pendekatan Genre-Based. Jurnal Ilmu Bahasa dan Sastra LINGUA, Vol 6 No 2, Agustus 2011 